HORTSCIENCE 25(4):451-453. 1990.

\title{
Photosynthesis as an Index of Turfgrass Growth Following Application of Herbicides
}

\author{
T.R. Willard ${ }^{1}$, C.M. Peacock ${ }^{2}$, and D.G. Shi11ing ${ }^{3}$ \\ Agronomy Department, University of Florida, Gainesville, FL 32611
}

Additional index words. sethoxydim, cloproxydim, fluazifop, St. Augustinegrass, bahiagrass, centipedegrass, phytotoxicity, postemergence grass herbicides

\begin{abstract}
The effects of sethoxydim, cloproxydim, and fluazifop on photosynthesis and growth of St. Augustinegrass [Stenotaphrum secundatum (Walt.) Kuntze 'Floralawn'], bahiagrass (Paspalum notatum var. saurae Parodi 'Pensacola'), and centipedegrass [Eremochloa ophiuroides (Munro.) Hack.] were evaluated to determine if photosynthesis could be used as a rapid, nondestructive measure of relative susceptibility. Field and greenhouse studies were conducted using infrared $\mathrm{CO}_{2}$ analysis to estimate photosynthesis. Under field conditions, St. Augustinegrass was susceptible to sethoxydim and fluazifop applications, as indicated by a $40 \%$ and $38 \%$ reduction in apparent photosynthesis, respectively. Bahiagrass incurred a respective $62 \%$ and $51 \%$ reduction in apparent photosynthesis from sethoxydim and fluazifop application. Growth of these species, as measured by foliage dry weight, was also inhibited by both herbicides. Centipedegrass growth was unaffected by sethoxydim, but was reduced $48 \%$ by fluazifop. Under greenhouse conditions, centipedegrass apparent photosynthesis was reduced by sethoxydim and cloproxydim ( $41 \%$ and $51 \%$, respectively), while fluazifop caused a $71 \%$ reduction. Growth of centipedegrass was significantly reduced only by fluazifop $(83 \%)$. These studies indicated that in vivo photosynthetic measurements may provide a sensitive, rapid, and nondestructive method for determining the susceptibility of turfgrasses to postemergence grass herbicides. chemical names used: 2-[1(ethoxyimino)butyl]-5-[2-(ethylthio) propyl]-3-hydroxy-2-cyclohexen-1-one (sethoxy$\operatorname{dim}) ;(E, E)$-2-[1-[[(3-chloro-2-propenyl) oxy]imino]butyl] -5-[2-(ethylthio) propyl]-3hydroxy-2-cyclohexen-1-one (cloproxydim); and butyl ester of 2-[4-[[5-(trifluoromethyl)-2-pyridinyl]oxy ]phenoxy]-propanoate(fluazifop).
\end{abstract}

St. Augustinegrass, centipedegrass, and bahiagrass are common turfgrass species grown in the southern United States (Beard, 1973). St. Augustinegrass is used primarily

Received for publication 1 Dec. 1988. Florida Agricultural Experiment Station Journal Series no. 9485. The cost of publishing this paper was defrayed in part by the payment of page charges. Under postal regulations, this paper therefore must be hereby marked advertisement solely to indicate this fact.

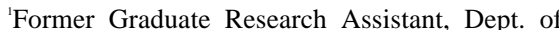
Agronomy. Current address: W.R. Landis Assoc., Inc., 102 N. Lee St., Valdosta, GA 316035126.

${ }^{2}$ Associate Professor, Ornamental Horticulture Dept. Current address: Dept. of Crop Science, North Carolina State Univ., Raleigh, NC 27695-7620. ${ }^{3}$ Assistant Professor, Dept. of Agronomy. for lawns and commercial turf where fine leaf texture is not required. Centipedegrass is used for lawns where low cultural intensity is desired. Bahiagrass is common along roadsides and other low-maintenance areas because of its excellent drought, disease, and insect tolerance.

In the southern United States, more than 100 weeds occur in turf (R. Dickens, personal communication). In Florida, $\approx 70$ weeds are found in turf, with 25 of these causing frequent problems (D. Hall, personal communication). These weeds cause significant economic losses due to the cost of chemical control, decreased turf quality, decreased land values, and increased sod harvesting costs. Of these 25 weeds, eight are annual grasses, with annual bluegrass (Poa annua L.), crabgrasses (Digitaria sp. Heister), goose- 
Table 1. Effect of sethoxydim and fluazifop at $0.28 \mathrm{~kg} \cdot \mathrm{ha}^{-1}$ on the $\mathrm{C}$ exchange rate of St. Augustinegrass and bahiagrass at 9 and 10 days after treatment, respectively. ${ }^{2}$

\begin{tabular}{lccc}
\hline \hline Treatment & $\begin{array}{c}\text { Apparent } \\
\text { photosynthesis }\end{array}$ & $\begin{array}{c}\text { Dark } \\
\text { respiration }\end{array}$ & $\begin{array}{c}\text { Gross } \\
\text { photosynthesis }\end{array}$ \\
\hline $\begin{array}{l}\text { St. Augustinegrass } \\
\text { Sethoxydim }\end{array}$ & $0.98 \mathrm{~b}$ & $\mathrm{CO}_{2}\left(\mathrm{mg} \cdot \mathrm{m}^{-2} \cdot \mathrm{s}^{-1}\right)$ & \\
Fluazifop & $1.00 \mathrm{~b}$ & $1.27 \mathrm{~b}$ & $2.55 \mathrm{~b}$ \\
$\quad$ Control & $1.62 \mathrm{a}$ & $1.46 \mathrm{~b}$ & $2.46 \mathrm{~b}$ \\
Bahiagrass & & $1.82 \mathrm{a}$ & $3.44 \mathrm{a}$ \\
Sethoxydim & $0.33 \mathrm{~b}$ & & \\
Fluazifop & $0.43 \mathrm{~b}$ & $0.80 \mathrm{~b}$ & $1.13 \mathrm{~b}$ \\
Control & $0.88 \mathrm{a}$ & $0.80 \mathrm{~b}$ & $1.23 \mathrm{~b}$ \\
\hline
\end{tabular}

${ }^{2}$ Mean separation at $P=0.05$ using Duncan's multiple range test. Data are the means of seven observations.

Table 2. The effect of sethoxydim and fluazifop at $0.28 \mathrm{~kg} \cdot \mathrm{ha}^{-1}$ on the growth of three warm-season turfgrasses. ${ }^{\mathrm{z}}$

\begin{tabular}{lccc}
\hline \hline & & Foliage dry wt $(\mathrm{g})$ & \\
\cline { 2 - 4 } Treatment & St. Augustinegrass & Bahiagrass & Centipedegrass \\
\hline Sethoxydim & $5.3 \mathrm{~b}$ & $56.8 \mathrm{~b}$ & $119.8 \mathrm{a}$ \\
Fluazifop & $5.0 \mathrm{~b}$ & $51.8 \mathrm{~b}$ & $60.5 \mathrm{~b}$ \\
Control & $16.8 \mathrm{a}$ & $84.8 \mathrm{a}$ & $116.0 \mathrm{a}$ \\
\hline
\end{tabular}

${ }^{2}$ Mean separation at $P=0.05$ using Duncan's multiple range test. Data are the mcan of seven observations.

Table 3. Effect of three postemergence grass herbicides on the $\mathrm{C}$ exchange rate and growth of centipedegrass at 8 and 12 days after treatment. ${ }^{z}$

\begin{tabular}{|c|c|c|c|c|c|}
\hline Treatment & $\begin{array}{c}\text { Dosage } \\
\left(\mathrm{kg} \cdot \mathrm{ha}^{-1}\right)\end{array}$ & $\begin{array}{c}\text { Apparent } \\
\text { photosynthesis }\end{array}$ & $\begin{array}{c}\text { Dark } \\
\text { respiration }\end{array}$ & $\begin{array}{c}\text { Gross } \\
\text { photosynthesis }\end{array}$ & $\begin{array}{c}\text { Foliage } \\
\text { dry wt } \\
(\mathrm{g})\end{array}$ \\
\hline & \multicolumn{5}{|c|}{$\mathrm{CO}_{2}\left(m g \cdot m^{-2} \cdot s^{-1}\right)$} \\
\hline 8 Days after treatment & & & & & \\
\hline Sethoxydim & 0.28 & $0.409 \mathrm{~b}$ & $0.170 \mathrm{ab}$ & $0.579 \mathrm{~b}$ & $\cdots$ \\
\hline Cloproxydim & 0.56 & $0.241 \mathrm{~b}$ & $0.167 \mathrm{~b}$ & $0.408 \mathrm{~b}$ & -.. \\
\hline Fluazifop & 0.28 & $0.136 \mathrm{c}$ & $0.101 \mathrm{c}$ & $0.236 \mathrm{c}$ & -.. \\
\hline Control & $\cdots$ & 0.725 a & $0.262 \mathrm{a}$ & $0.987 \mathrm{a}$ & --- \\
\hline \multicolumn{6}{|l|}{12 Days after treatment } \\
\hline Sethoxydim & 0.28 & $0.346 \mathrm{~b}$ & $0.400 \mathrm{a}$ & $0.746 \mathrm{a}$ & $1.38 \mathrm{a}$ \\
\hline Cloproxydim & 0.56 & $0.289 \mathrm{~b}$ & $0.410 \mathrm{a}$ & $0.699 \mathrm{~b}$ & $0.89 \mathrm{a}$ \\
\hline Fluazifop & 0.28 & $0.172 \mathrm{~b}$ & $0.257 \mathrm{~b}$ & $0.429 \mathrm{c}$ & $0.18 \mathrm{~b}$ \\
\hline Control & $\cdots$ & $0.592 \mathrm{a}$ & $0.431 \mathrm{a}$ & $1.023 \mathrm{a}$ & $1.07 \mathrm{a}$ \\
\hline
\end{tabular}

${ }^{x}$ Mean separation at $P=0.05$ using Duncan's multiple range test. Data are the means of seven observations.

grass [Eleusine indica (L.) Gaerthn.], and crowfootgrass [Dactyloctenium aegyptium (L.) Beauv.] dominating.

Selective preemergence herbicides are more effective and less injurious to turf than are most postemergence herbicides. While timing of preemergence herbicide applications is critical to obtain adequate weed control, variability in weed emergence makes proper timing difficult. Therefore, selective postemergence grass herbicides sometimes need to be used. These are most effective when weeds are small and actively growing. Tolerance of warm-season turfgrasses varies with species and the amount of herbicide applied. Hosaka et al. (1984) evaluated the response of 27 temperate and 28 tropical seedling grasses to postemergence applications of sethoxydim. None of the grasses examined survived sethoxydim applications of 0.28 or $0.56 \mathrm{~kg} \cdot \mathrm{ha}^{-1}$. Willard and Currey (1985) found that when seven postemergence grass herbicides were studied, none selectively controlled tropical crabgrass [Digitara ciliaris (Retz.) Keel.] in 'Floratam' St. Au-
Gainesville, Fla., in 1983 to measure C exhange rate and growth of 'Pensacola' bahiagrass, centipedegrass, and 'Floralawn' St. Augustinegrass following applications of sethoxydim and fluazifop. The two experiments were initiated on 31 July and 25 Oct., respectively. The $1.5 \times 1.5-\mathrm{m}$ plots of each turfgrass species were treated with $0.28 \mathrm{~kg}$ a.i./ha of sethoxydim and fluazifop using a $\mathrm{CO}_{2}$-pressurized plot sprayer calibrated to deliver 187 liters $\cdot$ ha $^{-1}$. Crop oil concentrate (Agri-dex, Helena Chemical Co., Alachua, Fla.) was added to the spray mixture at 2.3 liters $\cdot h^{-1}$. Untreated control plots were included. The soil type was an Arredondo fine sand (loamy, siliceous, hyperthermic Grossarenic Paleudult).

To evaluate the effects of postemergence grass herbicides on photosynthesis, the drawdown method, as described by Peters et al. (1974), was used. This method involved the continuous measurement of $\mathrm{CO}_{2}$ decline via infrared gas analysis in air circulated through a mylar chamber placed over a known land area. The $\mathrm{C}$ exchange rate, expressed in $\mathrm{mg}$ $\mathrm{CO}_{2} / \mathrm{m}^{2}$ per sec, was determined from $\mathrm{CO}_{2}$ depletion over 1 to $5 \mathrm{~min}$ in full sunlight with $>1600 \mu \mathrm{mol} \cdot \mathrm{s}^{-1} \cdot \mathrm{m}^{-2}$ photosynthetic photon flux (PPF) and in the dark. The sum of the $\mathrm{C}$ exchange rate in the light (apparent photosynthesis) and the absolute value in the dark (dark respiration) yielded gross photosynthetic $\mathrm{C}$ exchange rate. The carbon exchange rate (CER) was calculated using the following formula: $\mathrm{CER}=(\mathrm{ppm} / \mathrm{min})\left(\mathrm{V}_{\mathrm{ml}}\right)(1 /$ L) $(273 /[273+\mathrm{C}])(1 / 60)(44 / 22.4)$, where $\mathrm{CER}=\mathrm{mg} \mathrm{CO} / \mathrm{m}^{2}$ per see; $\mathrm{ppm}=\mu \mathrm{CO}_{2} /$ liter; $\mathrm{V}_{\mathrm{ml}}=$ volume of chamber in milliliters; $\mathrm{L}=$ land area in square meters; 44/ $22.4=M r$ of $\mathrm{CO}_{2}$ in $\mathrm{mg} /$ volume of 1 mole of $\mathrm{CO}_{2}$ in milliliters; $273 /(273+\mathrm{C})=$ correction factor to degrees $\mathrm{K}$.

Photosynthetic measurements were made using a transparent $1.033-\mathrm{m} 3$ mylar chamber, covering $0.76 \mathrm{~m}^{2}$ of plot area. Air was recirculated at a rate of 1.0 liter $\cdot \mathrm{min}^{-1}$ using an electric pump. An electric fan mixed the air within the chamber. Air leaving the chamber passed through a column containing desiccant to remove water vapor before entering a Beckman (Model 865) infrared gas analyzer (Beckman Instruments, Fullerton, Calif.) that was calibrated using reference nitrogen $\mathrm{N}_{2}-\mathrm{CO}_{2}$ gas mixtures containing 210 ppm $\mathrm{CO}_{2}$ (low end of scale) and $330 \mathrm{ppm}$ $\mathrm{CO}_{2}$ (high end of scale). Temperature within the chamber was monitored using a thermocouple and a Wescor TH-65 digital TC thermometer (Wescor, Logan, Utah). The C exchange rate and temperatures were automatically recorded on a Soltec 1243 recorder (Soltec, Sun Valley, Calif.). Photosynthetic photon flux was monitored with a LI-COR (model LI-185A) quantum radiometer/photometer (LI-COR, Lincoln, Neb.) to assure that measurements were taken in light with an intensity of at least $1600 \mu \mathrm{mol} \cdot \mathrm{s}^{-1} \cdot \mathrm{m}^{-2}$. Apparent $\mathrm{C}$ exchange rate was measured until a constant decline in $\mathrm{CO}^{2}$ was attained for at least $1 \mathrm{~min}$. The chamber was then covered with black to obtain dark respiration measurements. 
Due to cloud cover and subsequent afternoon rain showers, only single day measurements were made during the first experiment, 9 days after treatment for St. Augustinegrass and 10 days after treatment for bahiagrass. Photosynthetic measurements were not obtained on centipedegrass, but foliage was harvested from these plots, as well as from the bahiagrass and St. Augustinegrass plots, at 11 days after treatment. The foliage from the entire plot area was harvested using a rotary mower set at 1 $\mathrm{cm}$ with a collection box mounted on the discharge shoot. Samples were then dried for $24 \mathrm{hr}$ at $100 \mathrm{C}$ before dry weights were determined.

For the second field experiment, $\mathrm{C}$ exchange rate measurements were taken daily for the first 3 days after treatment. After this time, weather conditions made it impractical to continue. All techniques and equipment for the second experiment were identical to those described for the first study. A splitplot design was used, with turfgrass species as the main plots and chemical treatments as the subplots. Four replications were used in the first experiment and three in the second. Analysis of variance was used to test for significant single factor effects and herbicide $x$ species interactions. Duncan's multiple range test was used to separate herbicide treatments within a turfgrass species (Helwig and Council, 1982)

To eliminate interference of weather on measurements of $\mathrm{C}$ exchange rate, an indoor system using greenhouse-grown centipedegrass was used to verify the effects obtained in the field studies. Centipedegrass plugs were planted into 2.8-liter plastic pots containing 2.4 liters of Arredondo fine sand on 19 Sept. 1983. On 10 Jan. 1984, plants were treated with sethoxydim, fluazifop, or cloproxydim at $0.28,0.28$, and $0.56 \mathrm{~kg}$ a.i./ha, respectively. Applications were made using a $\mathrm{CO}_{2}$ pressurized sprayer calibrated to deliver 187 liters $\cdot \mathrm{ha}^{-1}$. Crop oil concentrate was added to the spray mixture at 2.3 liters $\cdot$ ha $^{-1}$. Untreated control plants were included. Plants were maintained before and after application in a greenhouse where the air was $27 \pm 6 \mathrm{C}$ with a light intensity of $800 \mu \mathrm{mol} \cdot \mathrm{s}^{-1} \cdot \mathrm{m}^{-2}$ and a natural photoperiod.

Plants were taken to the laboratory daily and allowed to acclimate for $2 \mathrm{hr}$ before $\mathrm{C}$ exchange rate measurements. Following daily readings, plants were returned to the greenhouse. The system used to measure $\mathrm{C}$ exchange rate was similar to that used for the field studies, except that an ANARAD (AR600R) infrared gas analyzer (ANARAD, Santa Barbara, Calif.) and a Perkin-Elmer recorder (Perkin-Elmer, Norwalk, Conn.) were used. The plants were placed in a $0.025-\mathrm{m}^{3}$ clear plastic chamber. Lighting was supplied by a metal halide lamp positioned above a water tank $3 \mathrm{~cm}$ deep to absorb heat. This system provided 1600 to $1850 \mu \mathrm{mol} \cdot \mathrm{s}^{-1} \cdot \mathrm{m}^{-2} \mathrm{PPF}$. Procedures for $\mathrm{C}$ exchange rate determination were identical to those used in the field studies.

Apparent photosynthesis and dark respiration were measured daily for the first 8 days and at 12 days after treatment, when shoot clippings were also collected and dry weights determined. A completely randomized design was used with three and four replications for the first and second greenhouse experiments, respectively. This experiment was conducted twice and analysis of variance and Duncan's multiple range test were used to analyze these data as previously described.

There was a significant two-way interaction $(P<0.05)$ between herbicides and species for both field and greenhouse experiments; therefore, these factors are presented separately. Sethoxydim and fluazifop significantly reduced apparent photosynthesis, dark respiration, and gross photosynthesis in St. Augustinegrass and bahiagrass turf (Table 1). Apparent photosynthesis was affected to a greater degree than dark respiration. For bahiagrass, sethoxydim reduced apparent photosynthesis and dark respiration $62 \%$ and $27 \%$, respectively. Gross photosynthesis of St. Augustinegrass was reduced $35 \%$ by sethoxydim and $29 \%$ by fluazifop. In bahiagrass, gross photosynthesis was reduced $43 \%$ and $38 \%$ by sethoxydim and fluazifop applications, respectively.

Visible foliar injury from the herbicide treatments was apparent when the physiological measurements were taken at 9 and 10 days. Extensive necrosis of the intercalary meristem region was evident at this time. Therefore, the foliar injury could have been due, at least in part, to the meristematic damage that severed the vascular connections to the leaves (Asare-Boamah and Fletcher, 1983; Swisher and Corbin, 1982). Essential, there was a reduction in the amount of leaf tissue capable of photosynthesis. St. Augustinegrass growth (Table 2) was severely reduced by sethoxydim $(68 \%)$ and fluazifop (70\%). Bahiagrass foliage was also significantly reduced by both herbicide treatments, with sethoxydim causing a $33 \%$ and fluazifop a $39 \%$ reduction compared to the untreated control plots. Centipedegrass growth was unaffected by sethoxydim treatments, but was reduced $48 \%$ by fluazifop. In the second field study, measurements were taken for the first 3 days after treatment only. There were no significant effects on apparent photosynthesis, dark respiration, or gross photosynthesis in any of the three turfgrasses from either sethoxydim or fluazifop (data not shown).

Centipedegrass was selected for use in the greenhouse studies because it exhibited the widest range of tolerance to the postemergence grass herbicides, as reported by Willard and Currey (1985). Treatment differences in apparent photosynthesis were not significant until 5 days after treatment, while differences in dark respiration were not significant until 8 days after treatment (data not shown). Table 3 summarizes the $\mathrm{C}$ exchange rate measurements for 8 and 12 days after treatment and the foliage dry weights taken at 12 days after treatment. By 8 days after treatment, centipedegrass injury was noticeable from the fluazifop treatment. All treatments reduced apparent photosynthesis, while only fluazifop and cloproxydim significantly reduced dark respiration. These data corroborate those found in the field studies regard- ing the differential effects of these herbicides on apparent photosynthesis and dark respiration. Gross photosynthesis at 12 days after treatment was significantly reduced by cloproxydim $(32 \%)$ and fluazifop $(58 \%)$. The difference in sensitivity to these two herbicides is also reflected in foliage dry weight reductions. There was no significant difference between the untreated control plants and those treated with either sethoxydim or cloproxydim; however, fluazifop reduced centipedegrass growth $83 \%$.

These data indicated that effects on photosynthesis from postemergence grass herbicides occurred at about the same time as the initial visual injury symptoms. Photosynthetic measurements did provide a quantitative, nondestructive, and sensitive measure of herbicide injury that could be an improvement over visual ratings, which are subjective in nature. However, the ultimate measure of herbicide susceptibility is biomass reduction. In all but two cases (the response of centipedegrass to sethoxydim and cloproxydim), reductions in photosynthesis and foliage dry weight due to the herbicide treatments were similar. In the case of the two exceptions, the reductions in photosynthesis caused by the herbicides must have been transient and therefore the magnitude of the physiological response was not manifested in a biomass-type response. Therefore, to be able to fully evaluate the utility of photosynthesis as a measure of herbicide susceptibility, studies should be conducted to confirm that a close relationship exists between reductions in biomass (long term) and photosynthesis (short and long term).

\section{Literature Cited}

Asare-Boamah, N.K. and R.A. Fletcher. 1983. Physiological and cytological effects of BAS9052-OH on corn (Zea mays) seedlings. Weed Sci. 31:49-55.

Beard, J.B. 1973. Turfgrass: Science and culture. Prentice-Hall, Englewood Cliffs, N.J.

Burton, J.D., J.W. Gronwald, D.A. Somers, J.A. Connelly, B.G. Gengenbach, and D.L. Wyse. 1987. Inhibition of plant acetyl-coenzyme A carboxylase by the herbicides sethoxydim and haloxyfop. Biochem. Biophys. Res. Comm. 148:1039-1044.

Gealy, D.R. and F.W. Slife. 1983. BAS-9052 effects on leaf photosynthesis and growth. Weed Sci. 31:457-461.

Helwig, J.T. and K.A. Council. 1982. SAS user's guide. SAS Institute, Inc., Cary, N.C.

Hosaka, H., H. Inaba, and H. Ishikawa. 1984. Response of monocotyledons to BAS-9052-OH. Weed Sci. 32:28-32.

Peters, D.B., B.F. Clough, R.A. Garves, and G.R. Stahl. 1974. Measurement of dark respiration, evaporation and photosynthesis in field plots. Agron. J. 66:460-462.

Secor, J. and C. Cséke. 1988. Inhibition of acetylCoA carboxylase activity by haloxyfop and tralkoxydim. Plant Physiol. 86:10-12.

Swisher, B.A. and F.T. Corbin. 1982. Behavior of BAS-9052-OH in soybean (Glycine max) and johnsongrass (Sorghum halepense) plant and cell cultures. Weed Sci. 30:640-650.

Willard, T.R. and W.L. Currey. 1985. Selectivity of postemergence grass herbicides in warm-season turfgrasses. Proc. Southern Weed Sci. Soc. 38:96. 